\title{
Bioaccumulation of Cadmium Content in Mushroom and Soil in Delhi-NCR Region of India
}

\author{
MONIKA JAIN $^{\mathrm{a}^{*}}$, V. K. GUPTA ${ }^{\mathrm{a}}$ and ASHOK KUMAR ${ }^{\mathrm{b}}$ \\ ${ }^{\text {a } D e p a r t m e n t ~ o f ~ C h e m i s t r y, ~ P . G . ~ C o l l e g e, ~ A m b a h, ~ J i w a j i ~ U n i v e r s i t y . ~ G w a l i o r, ~ I n d i a ~}$ \\ ${ }^{\mathrm{b}}$ Department of Chemistry, St. John College, Agra University, Agra, Uttar Pradesh, India \\ jmoni30@gmail.com
}

Received 24 January 2013 / Accepted 16 February 2013

\begin{abstract}
This study was carried to estimate the distribution and accumulation of cadmium in wildly grown edible mushroom and its underlying soil from surrounding areas of Delhi-NCR. Samples were collected from regions polluted with industrial drainage and heavy traffic. Cadmium accumulations in these were compared with that of wildly grown mushroom collected from non polluted cultivated and remote residential areas of Delhi. Commercial samples of mushroom were also collected and analyzed. All these study was conducted on four different varieties of mushroom i.e. Button mushroom (Agaricus bisporus), Oyster mushroom (Pleurotus sajor-caju), Milky mushroom (Calocybe indica) and Shiitake (Lentinus edodes). The levels of cadmium were analyzed using Flame Atomic Absorption Spectrometry. The results from the two way ANOVA showed that there was significant variation in trace metal concentrations at different locations. From correlation analysis it was found trace metals concentration in soil and mushroom samples were positively correlated.
\end{abstract}

Keywords: Cadmium, Bioaccumulation, Heavy metals, Mushroom, Soil, Flame Atomic absorption Spectrometry

\section{Introduction}

Toxicological and environmental studies have prompted interest in the determination of toxic elements in food. Mushrooms surely do not constitute a significant portion of the human diet, but the consumption of wild and cultivated mushrooms has become increasingly popular in recent years. There are several reasons why mushroom poisoning can occur among people and the high heavy metal concentrations in some edible fungi is a known source as chronic poisoning ${ }^{1}$. Higher fungi are able to bioconcentrate or exclude specific metal ions and analyzing the fruit body-to-soil ratios of metals it has been found the bioconcentration factor (BCF). This is due to the difference between species, to their behavior (parasitic, saprophytic, or mycorrhizal) and to the environmental contamination, but it has not always been possible to decide on bioaccumulation or bioexclusion only for these reasons. Many species of mushrooms possess the ability to effectively take up and accumulate heavy metals ${ }^{2-5}$. 
Cadmium is a highly toxic metal with a natural occurrence in soil, but it is also spread in the environment due to human activities. Cadmium is known as a principal toxic metal, since excessive cadmium exposure may give rise to renal, pulmonary, hepatic, skeletal, reproductive effects and cancer. It was reported that cadmium is accumulated mainly in kidneys, spleen and liver and its blood serum level increases considerably following mushroom consumption ${ }^{5}$. Cadmium is a byproduct in the production of zinc and lead and the pyrometallurgical production of zinc is the most important anthropogenic source into the environment. Other major sources are fossil fuel combustion and waste incineration. Thus, cadmium seems to be the most deleterious among heavy metals in mushrooms. It can be taken up directly from water and to some extent from air and it has a tendency to accumulate in both plants and animals. Mushrooms, in particular, can be very rich in cadmium and its accumulation has been widely demonstrated ${ }^{2,6}$.

\section{Experimental}

Samples of soils and four different species of wildly growing edible mushrooms; Button mushroom (Agaricus bisporus), Oyster mushroom (Pleurotus sajor-caju), Milky mushroom (Calocybe indica) and Shiitake (Lentinus edodes) were collected from North Delhi Border and Sonepat region, India during monsoon. The area studied was divided into area of industrial activity (Location 1, L1), road side area on National Highway NH 1 with heavy vehicular traffic and state highway crossing NH1 (Location 2, L2) and remote residential area (Location 3, L3). Commercial samples obtained from Azadpur Market, Delhi (Location 4, L4) whereas cultivated samples (Location 5, L5) were collected from Mushroom research centre, Sonepat (NCR). Soil samples were taken at measurement points at a depth of approximately $0-15 \mathrm{~cm}$. The samples were dried at $105{ }^{0} \mathrm{C}$ and ground to pass through 200 mesh sieve and transferred to polyethylene bottles until analysis. No prior washing was done to mushroom samples and they were dried as such at $105{ }^{\circ} \mathrm{C}$ for $24 \mathrm{~h}$. The dried samples were ground, then homogenized using an agate pestle and stored in polyethylene bottles until analysis. Sub samples were analyzed for moisture content at $103{ }^{\circ} \mathrm{C}$ using tray dehydrator.

\section{Sample preparation}

For soil analysis one gram of dried soil sample was taken in a $100 \mathrm{~mL}$ conical flask with $10 \mathrm{~mL}$ of concentrated nitric acid and kept overnight. The flask was placed on a hot plate inside a fume hood for digestion, heated at a temperature of $70^{\circ} \mathrm{C}$ for $1 \mathrm{~h}$, and then kept it for cooling for $30 \mathrm{~min}$ and $5 \mathrm{~mL}$ of aquaregia, a mixture of conc. nitric acid $\left(\mathrm{HNO}_{3}\right)$ and perchloric acid $\left(\mathrm{HClO}_{4}\right)(\mathrm{AR} 70 \%$, Merck) in a ratio of $4: 1$, was added and again the flask was placed on hot plate, heated at a temperature of $80^{\circ} \mathrm{C}$ for $2 \mathrm{~h}$. Then it was cooled for $1 \mathrm{~h}$ and transferred to $50 \mathrm{~mL}$ volumetric flask through filtration (Whatmann 42) and the final volume was made up to the mark with double distilled water, mixed well by shaking and let settle for at $15 \mathrm{~h}$. The resultant supernatant was analyzed.

For mushroom analysis, $1 \mathrm{~g}$ of ground-dried mushroom sample was placed in a small beaker. $10 \mathrm{~mL}$ of concentrated $\mathrm{HNO}_{3}$ was added \& allowed it to stand overnight. It was heated on a hot plate carefully until the production of red $\mathrm{NO}_{2}$ fumes has been ceased and then kept for cooling and a small amount $(2-4 \mathrm{~mL})$ of $70 \% \mathrm{HClO}_{4}$ was added. Heated again and allowed to operate a small volume. Transferred the sample to a $50 \mathrm{~mL}$ flask and diluted to volume with double distilled water. Then the quantification of metallic content of digested samples was carried out with the FAAS (Flame Atomic Absorption Spectrophotometer). 


\section{Analytical method of soil and mushroom}

Cadmium in samples was analyzed using Flame Atomic Absorption Spectrophotometer (PerkinElmer, ANALYST 100). Air-acetylene flame was used for determination of metal content.

\section{Results and Discussion}

\section{Concentration of cadmium in mushroom samples}

Results showed that location had significant variation in cadmium concentration in mushroom. Highest mean cadmium concentration was recorded in samples of roadside area i.e. $7.78 \mathrm{mg} / \mathrm{kg} \mathrm{dw}$ in the first year and $8.0 \mathrm{mg} / \mathrm{kg} \mathrm{dw}$ in the second year while minimum mean cadmium concentration was found in the cultivated samples i.e. $0.70 \mathrm{mg} / \mathrm{kg} \mathrm{dw}$ in the first year and $0.79 \mathrm{mg} / \mathrm{kg} \mathrm{dw}$ in the second year. In both the year roadside area recorded the highest mean cadmium accumulation followed by industrial drainage area, commercial area and remote residential area.

Significant differences $(\mathrm{p}<0.01)$ was there in samples collected from different locations. The samples analyzed showing maximum accumulation in roadside samples, however, the sources of $\mathrm{Cd}$ in the urban areas are much less well defined than those of lead, but metal plating and tire rubber were considered the likely sources of $\mathrm{Cd}^{7}$. In the absence of any major industry in the sampling sites, the levels of $\mathrm{Cd}$ could be due to lubricating oils and/or old tires that are frequently used and the rough surfaces of the roads which increase the wearing of tires. It was stated that $\mathrm{Cd}$ levels in vehicular exhaust emissions have been related to the composition of gasoline motor oils, car tires and roadside deposition of the residues of those materials as well as traffic density ${ }^{8}$. This is followed by industrial drainage samples and commercial area. The cadmium level in all studied species from both areas can be considered to be high and mushrooms from these sites should not be consumed. In both the years all the cultivated and remote residential area samples were found lower than the safe limit of Indian Prevention of Food Adulteration Act (PFA) i.e. $1.5 \mathrm{mg} / \mathrm{kg} \mathrm{dw}{ }^{9}$ but higher than more stringent CODEX safe limit of $0.2 \mathrm{mg} / \mathrm{kg}$. The WHO mentions maximum permissible levels in raw plant materials for cadmium which amount to $0.30 \mathrm{mg} / \mathrm{kg}$. Current Czech statutory limits for the cadmium contents in wild-growing edible mushrooms are 2.0 $\mathrm{mg} / \mathrm{kg}$ dry matter. In the EU, the limit of $2.0 \mathrm{mg} / \mathrm{kg}$ dry matter is valid for cultivated mushroom $^{10}$. Another consideration from the health risk of view, from mushroom consumption is the FAO/WHO provisional tolerable weekly intake ${ }^{11}$. There is limit of 7 microgram per $\mathrm{kg}$ of bodyweight for cadmium. For intake calculations, usually a $300 \mathrm{~g}$ portion of fresh mushrooms per meal is assumed, which contains $30 \mathrm{~g}$ of dry matter. A tolerable weekly intake for a person with a bodyweight of $60 \mathrm{~kg}$ is thus reached by a single portion of $300 \mathrm{~g}$ of fresh mushrooms containing $14 \mathrm{mg} / \mathrm{kg}$ dry matter of cadmium ${ }^{5}$.

Cadmium concentration in Button mushroom (Agaricus bisporus), Shiitake (Lentinula edodes), Milky mushroom (Calocybe indica) and the cultivar Oyster mushroom (Pleurotus sajor-caju) in the both the years was ranged from 0.72 to $15.7 \mathrm{mg} / \mathrm{kg} \mathrm{dw}, 1.0$ to $12.0 \mathrm{mg} / \mathrm{kg}$ $\mathrm{dw}, 0.41$ to $14.3 \mathrm{mg} / \mathrm{kg}$ dw and 0.38 to $8.20 \mathrm{mg} / \mathrm{kg} \mathrm{dw}$. When compared in different species highest cadmium accumulation was in Button mushroom. Very high concentrations of cadmium have been reported in the genus Agaricus ${ }^{12-14,2-4}$. Mean cadmium concentrations in different varieties of mushroom are shown in Table 1 and Table 2 and Figure 1. Cadmium contents of mushroom samples in the literature have been reported ${ }^{15-21}$ to be in the ranges: $0.81-7.50 \mathrm{mg} / \mathrm{kg}, 0.10-0.71 \mathrm{mg} / \mathrm{kg}, 0.12-2.60 \mathrm{mg} / \mathrm{kg}, 0.28-1.6 \mathrm{mg} / \mathrm{kg}, 0.2-29.1 \mathrm{mg} / \mathrm{kg}, 0.26-3.24$ $\mathrm{mg} / \mathrm{kg}$ and 0.06 to $0.58 \mathrm{mg} / \mathrm{kg}$ respectively. Our cadmium levels were within those reported in the literature. 
Table 1. Mean cadmium concentration $(\mathrm{mg} / \mathrm{kg} \mathrm{dw})$ in different varieties of mushroom in the year 2009

\begin{tabular}{cccccc}
\hline $\begin{array}{c}\text { Sampling } \\
\text { sites }\end{array}$ & $\begin{array}{c}\text { Agaricus } \\
\text { bisporus }\end{array}$ & $\begin{array}{c}\text { Pleurotus } \\
\text { sajor-caju }\end{array}$ & $\begin{array}{c}\text { Calocybe } \\
\text { indica }\end{array}$ & $\begin{array}{c}\text { Lentinula } \\
\text { edodes }\end{array}$ & Mean \\
\hline L1 & 5.74 & 4.49 & 4.46 & 4.35 & 4.76 \\
L2 & 10.34 & 4.50 & 9.22 & 7.06 & 7.78 \\
L3 & 1.72 & 0.45 & 2.06 & 1.99 & 1.56 \\
L4 & 5.56 & 4.44 & 5.83 & 4.69 & 5.13 \\
L5 & 0.90 & 0.54 & 0.67 & - & 0.70 \\
Mean & 4.85 & 2.88 & 4.45 & 4.52 & \\
& & Location & Variety & Location x & \\
& & 0.38 & 0.34 & Variety & \\
& S.E.(m) & 1.07 & 0.96 & 2.14 & \\
\hline
\end{tabular}

Table 2. Mean cadmium concentration $(\mathrm{mg} / \mathrm{kg} \mathrm{dw})$ in different varieties of mushroom in the year 2010

\begin{tabular}{cccccc}
\hline $\begin{array}{c}\text { Sampling } \\
\text { sites }\end{array}$ & $\begin{array}{c}\text { Agaricus } \\
\text { bisporus }\end{array}$ & $\begin{array}{c}\text { Pleurotus } \\
\text { sajor-caju }\end{array}$ & $\begin{array}{c}\text { Calocybe } \\
\text { indica }\end{array}$ & $\begin{array}{c}\text { Lentinula } \\
\text { edodes }\end{array}$ & Mean \\
\hline L1 & 5.14 & 3.06 & 5.14 & 4.13 & 4.37 \\
L2 & 10.59 & 4.80 & 9.55 & 7.06 & 8.00 \\
L3 & 2.16 & 0.40 & 1.95 & 1.91 & 1.60 \\
L4 & 4.07 & 5.31 & 4.33 & 4.46 & 4.54 \\
L5 & 0.92 & 0.65 & 0.79 & - & 0.79 \\
Mean & 4.58 & 2.84 & 4.35 & 4.39 & \\
& & Location & Variety & Location x & \\
& & 0.34 & 0.31 & Variety & \\
& S.E.(m) & 0.69 & 0.86 & 1.93 & \\
& LSD $(0.05$ P) & 0.96 & & &
\end{tabular}

๓V1 $\approx \mathrm{V} 2=\mathrm{V} 3 \approx \mathrm{V} 4$

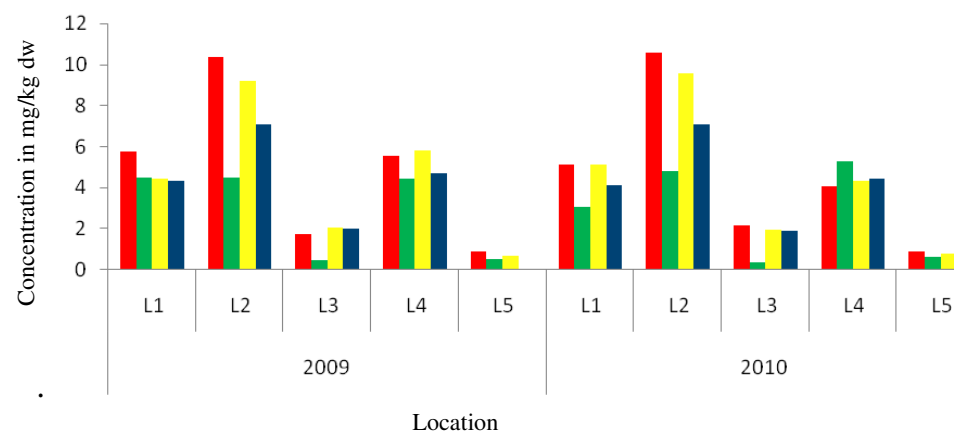

Figure 1. Cadmium concentrations (as $\mathrm{mg} / \mathrm{kg} \mathrm{dw}$ ) of different mushroom species at various locations

\section{Concentration of cadmium in soil samples}

As shown in mushroom, location had significant variation $(\mathrm{p}<0.01)$ in cadmium concentration in soil. Highest cadmium concentration was recorded in roadside area i.e. $2.71 \mathrm{mg} / \mathrm{kg} \mathrm{dw}$ in 
the first year and $2.77 \mathrm{mg} / \mathrm{kg} \mathrm{dw}$ in the second year while minimum in the samples collected from cultivated area i.e. $0.40 \mathrm{mg} / \mathrm{kg} \mathrm{dw}$ in the first year and $0.50 \mathrm{mg} / \mathrm{kg} \mathrm{dw}$ in the second year. Mean cadmium concentration of the mushroom samples at different locations is shown in Table 3 and Table 4 and Figure 2. The cadmium level in all studied soil samples except remote residential area and cultivated area were higher than the safe limit of Indian Prevention of Table 3.

Table 3. Mean cadmium concentration ( $\mathrm{mg} / \mathrm{kg} \mathrm{dw}$ ) in soil in the year 2009

\begin{tabular}{cccccc}
\hline $\begin{array}{c}\text { Sampling } \\
\text { sites }\end{array}$ & $\begin{array}{c}\text { Agaricus } \\
\text { bisporus }\end{array}$ & $\begin{array}{c}\text { Pleurotus } \\
\text { sajor-caju }\end{array}$ & $\begin{array}{c}\text { Calocybe } \\
\text { indica }\end{array}$ & $\begin{array}{c}\text { Lentinula } \\
\text { edodes }\end{array}$ & Mean \\
\hline L1 & 1.38 & 1.87 & 1.41 & 1.41 & 1.52 \\
L2 & 1.29 & 3.55 & 3.29 & 2.70 & 2.71 \\
L3 & 0.16 & 0.55 & 0.58 & 0.58 & 0.47 \\
L5 & 0.41 & 0.38 & 0.41 & - & 0.40 \\
Mean & 0.81 & 1.59 & 1.42 & 1.56 & \\
& & Location & Variety & Location x \\
& & 0.08 & 0.08 & Variety & \\
& S.E.(m) & 0.17 & \\
& LSD (0.05 P) & 0.24 & 0.21 & 0.47 & \\
\hline
\end{tabular}

Table 4. Mean cadmium concentration $(\mathrm{mg} / \mathrm{kg} \mathrm{dw})$ in soil in the year 2010

\begin{tabular}{cccccc}
\hline $\begin{array}{c}\text { Sampling } \\
\text { sites }\end{array}$ & $\begin{array}{c}\text { Agaricus } \\
\text { bisporus }\end{array}$ & $\begin{array}{c}\text { Pleurotus } \\
\text { sajor-caju }\end{array}$ & $\begin{array}{c}\text { Calocybe } \\
\text { indica }\end{array}$ & $\begin{array}{c}\text { Lentinula } \\
\text { edodes }\end{array}$ & Mean \\
\hline L1 & 1.09 & 1.87 & 1.83 & 1.52 & 1.58 \\
L2 & 1.91 & 3.65 & 2.83 & 2.72 & 2.77 \\
L3 & 0.12 & 0.79 & 0.69 & 0.68 & 0.57 \\
L5 & 0.50 & 0.56 & 0.45 & - & 0.50 \\
Mean & 0.90 & 1.72 & 1.45 & 1.64 & \\
& & Location & Variety & Location x & \\
& & 0.08 & 0.07 & 0.16 & \\
& S.E.(m) & 0.23 & 0.21 & 0.46 & \\
\hline
\end{tabular}

a $1=\mathrm{V} 2=\mathrm{V} 3=\mathrm{V} 4$

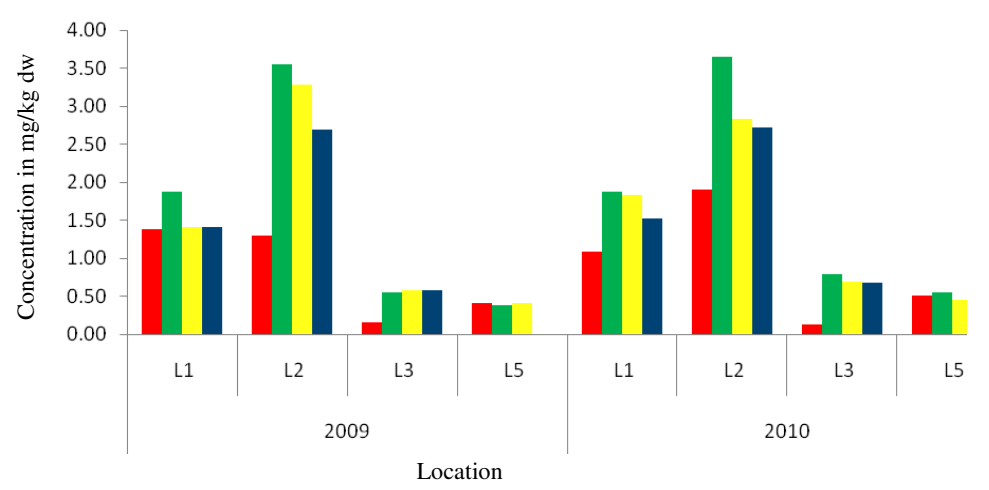

Figure 2. Cadmium concentrations (as $\mathrm{mg} / \mathrm{kg} \mathrm{dw}$ ) in soil at different locations

(V1: Agaricus bisporus, v2 : Pleurotus sajor-caju, v3 : Calocybe indica and v4: Lentinus edodes are four different varieties of mushroom) 
Food adulteration act (PFA) i.e. $6 \mathrm{mg} / \mathrm{kg} \mathrm{dw}$ and WHO for cadmium in soil amount to $0.85 \mathrm{mg} / \mathrm{kg}$. Cadmium 0-1 mg/kg in soils of indicates non-contamination, $1-3 \mathrm{mg} / \mathrm{kg}$ indicates slight contamination and $3-10 \mathrm{mg} / \mathrm{kg}$ indicates a contaminated ${ }^{22}$. Result showed that soil samples of different mushroom varieties had significant variation $(\mathrm{P}<0.01)$ in cadmium concentration. Maximum mean cadmium concentration in the both years was found in soil of Oyster (Pleurotus sajor-caju) followed by Shiitake (Lentinula edodes) and Milky (Calocybe indica) and the minimum cadmium concentration was in Button mushroom (Agaricus bisporus) as shown in Table 3 and 4. In both the years, cadmium concentration of the soil of Oyster (Pleurotus sajor-caju), Shiitake (Lentinula edodes), Milky (Calocybe indica) and Button mushroom (Agaricus bisporus) was found in the range of 0.23 to $5.29 \mathrm{mg} / \mathrm{kg} \mathrm{dw}, 0.38$ to $3.53 \mathrm{mg} / \mathrm{kg} \mathrm{dw}, 0.24$ to $4.78 \mathrm{mg} / \mathrm{kg} \mathrm{dw}$ and 0.09 to $15.7 \mathrm{mg} / \mathrm{kg}$ dw. But the differences in the soil of varieties i.e. Oyster and Milky was not statistically significant ( $\mathrm{P}>0.05)$.

\section{Relationship between mushroom metal concentration and underlying soil metal concentration}

Comparing the concentration of cadmium in the fruiting body and the concentration in the substratum that the mushrooms grew on, we obtain the bioaccumulation factor. The bioaccumulation factor represents the pollutant concentration in mushrooms comparing with the environment concentration (in soil) ${ }^{23}$. For a plant or mushroom to be efficient tool in the polluted soil bioremediation, the bioaccumulation factor ${ }^{24}$ have to be higher than 1 . The significant relationships between concentration of heavy metals in mushrooms and soil were further substantiated by performing correlation analysis. Statistically significant correlation coefficients $(r>0.515$ at 0.05 probability level) were established between metal concentrations in mushroom and soil with different varieties. The values of correlation coefficients between metal concentrations are given in Figure 3 with their respective graphs.
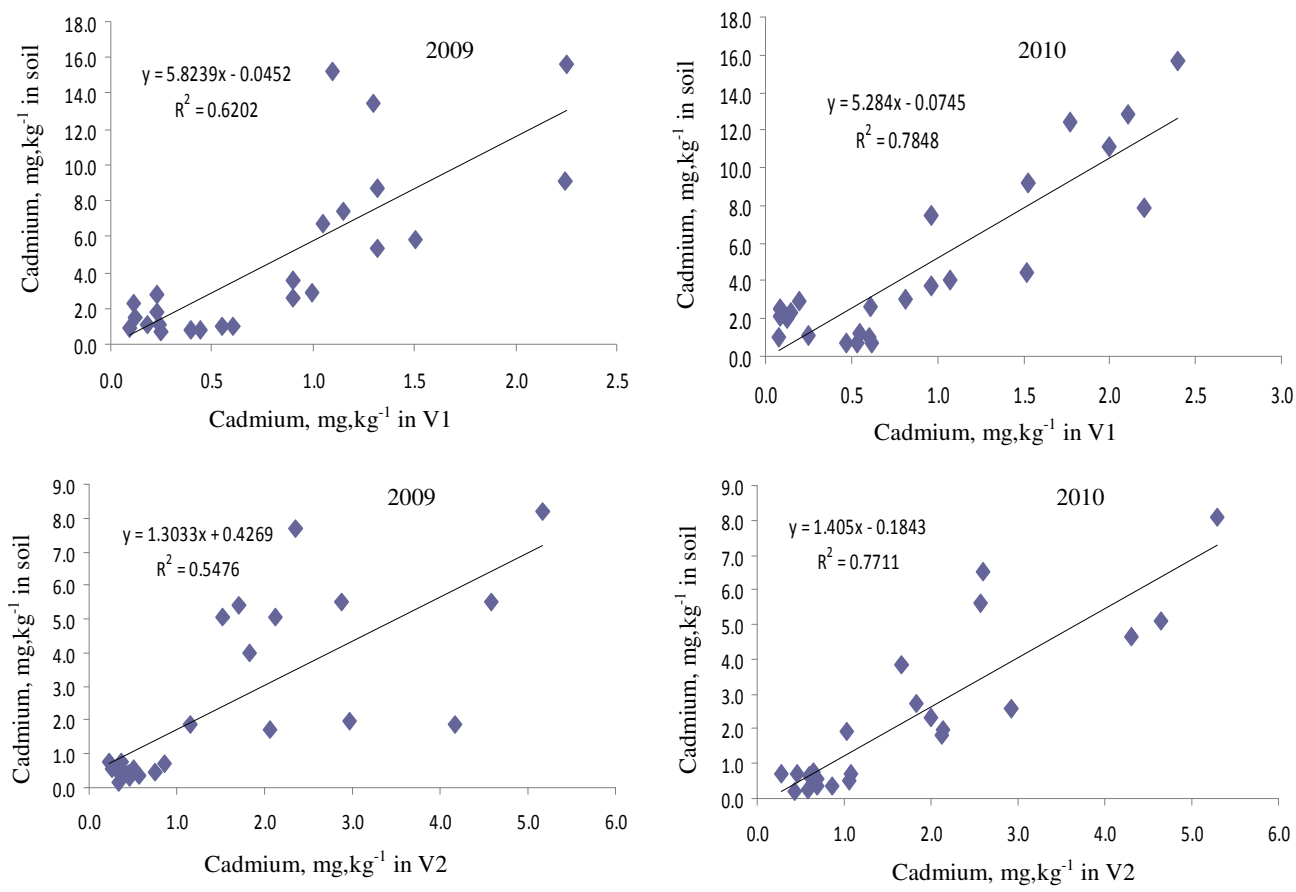

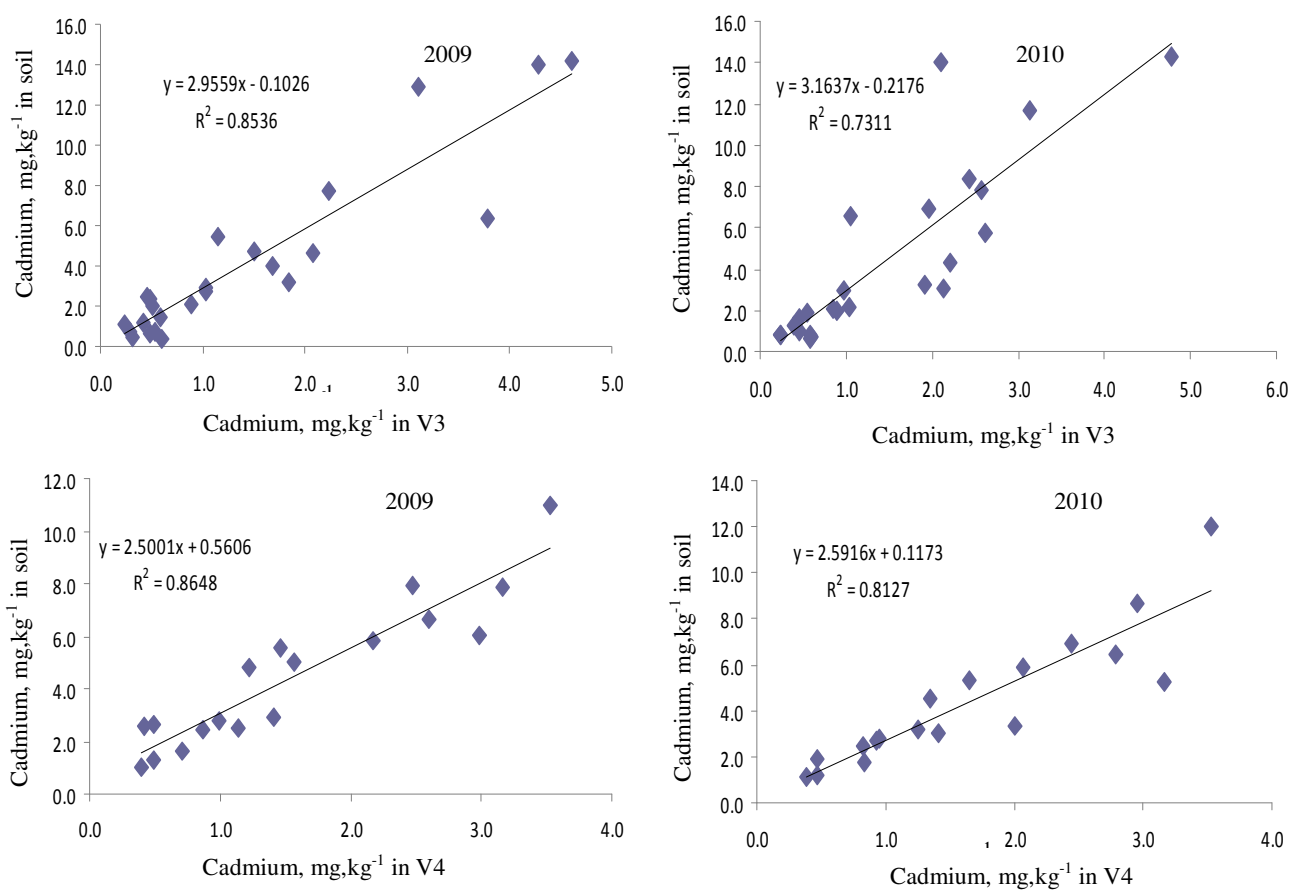

Figure 3. Relationship between cadmium concentration in various mushroom varieties and their underlying soil

The concentrations of cadmium have been found higher in mushroom than in underlying soil. Agaricus species have shown highest BCF ( 7.8 to 13.9, in some case BCF is up to 28.4). This shows agaricus to be a good accumulator, and hence can be used as indicator of cadmium pollution. Milky and Shiitake variety have also shown the accumulation whereas oyster mushroom has lowest accumulation. In a review of metal concentration in edible mushrooms, it was found that only species from Agaricus genus showed high cadmium concentrations greater than $10 \mathrm{mg} / \mathrm{kg}^{5}$. It was also observed Agaricus bisporus contains high cadmium concentration irrespective of soil concentration, showing accumulation of cadmium is more species specific than its level in underlying soil. High Cd concentrations were probably not caused by pollution but by species-dependent factors, so we agree with the opinion of other authors ${ }^{14}$. However, others found no correlation between the cadmium contents of mushrooms and that of the soil or substrate ${ }^{24}$. He suggested that cadmium could be a growth stimulation factor could prove to be of taxonomical value and was not the result of environmental contamination with $\mathrm{Cd}$ from the soil.

\section{Conclusion}

In present study, on the basis of data evaluation it has been found that location has significant role in concentration of cadmium. Samples collected near industrial drainage and highway were highly contaminated and showed higher cadmium concentration. Remote residential area and cultivated samples on the contrary don't have cadmium concentration higher than permitted limits.

Analysis showed positive correlation between concentration of cadmium in mushroom and soil. This infers that mushroom can be used as bio indicators of cadmium pollution. 
Also they can be used for phytoremediation. Frequent analysis of cadmium accumulation in both soil and mushroom should be done in this area to avoid possible risk to human health due to this.

\section{References}

1. Tüzen M, Ozdemir M and Demirbas A, Food Chem., 1998, 63(2), 247-251.

2. Kojo M R and Lodenius M, Angew Botanik., 1989, 63, 279-292.

3. Kalac P, Burda J and Staskova I, Sci Total Environ., 1991, 105, 109-119.

4. Falandysz J, Danisiewicz D and Bona H, Bromatologia I Chemia Toksykologiczna, 1994, 27(2), 129-134.

5. Kalac P and Svoboda L, Food Chem., 2000, 69(3), 273-281.

6. Stijve T and Besson R, Chemosphere, 1976, 5(2), 151-158.

7. Hewitt N C and Rasheed M B, Appl Organomet Chem., 1988. 2, 95-100.

8. Lagerwerff J V and Specht A W, Env Sci Tech., 1970, 4(7), 583-586.

9. Sharma K R, Agrawal M and Marshall M F, Food Chem Toxicol., 2009, 47(3), 583-591.

10. European Commission, Office for Official publications of the European Communities, Luxembourg, Council Directive 66/278/EEC, European Commission (EC), 2001.

11. FAO/WHO, Expert Committee on Food Additives, Summary and Conclusions. Fiftythird Meeting, Rome, 1999.

12. Lodenius M, Kuusi T, Laaksovirta K, Liukkonen-Lilja H and Piepponen S, Annales Botanici Fennici., 1981, 8(2), 183-186.

13. Schmitt J A and Meisch H U, Trace Elements Medicine, 1985, 2, 163-166.

14. Yilmaz F, Mustafa I and Melek M, Turk J Bot., 2003, 27(1), 45-56.

15. Svoboda L, Zimmermannová K and Kalac P, Sci Total Environ., 2000, 246(1), 61-67.

16. Mendil D, Uluozlu O D, Hasdemir E and Caglar A, Food Chem., 2004, 88(2), 281-285.

17. Malinowska E, Szefer, P and Falandaysz J, Food Chem., 2004, 84, 405- 416.

18. Mendil D, Uluözlü O D, Tüzen M, Hasdemir E and Sarı H, Food Chem., 2005, 91(3), 463-467.

19. Rudawska M and Leski T, Sci Total Environ., 2005, 339(1-3), 103-115.

20. Yamaç M, Yıldız D, Sarıkurkcu C, Mustafa Çelikkollu and Halil Solak M, Food Chem., 2007, 103(2), 263-267.

21. Fangkun Zhu, Li Qu, Wenxiu Fan, Meiying Qiao, Hailing Hao and Xuejing Wang, Environmental Monitoring Assessment, 2011, 179(1-4), 191-199.

22. Alloway B J, Heavy Metals in Soils, $2^{\text {nd }}$ Ed., Chapman \& Hall, London, 1995.

23. Scragg A, Environmental Biotechnology, Oxford University Press, New York, 2005.

24. Tyler G, Trans Brit Mycolog Soc., 1980, 74(1), 41-49. 